Prace Literackie LVIII

Wrocław 2018

https://doi.org/10.19195/0079-4767.58.11

ŁUKASZ PIASKOWSKI

ORCID: 0000-0002-3528-4301

Uniwersytet Wrocławski

\title{
Polacy z miasteczka Hameln. Językowo-muzyczne strategie mitologizacji i demitologizacji rzeczywistości w poezji Władysława Sebyły
}

Znana niemiecka legenda o pstrokato odzianym wędrownym grajku zwanym szczurołapem głosi, że przybył on do opanowanego przez szczury miasta Hameln, ażeby zaoferować swe usługi. Mieszczanie sfrustrowani dokuczliwymi gryzoniami zgodzili się, zobowiązując się do sowitej zapłaty po dobrze wykonanej pracy. Flecista 26 czerwca 1284 roku spełnił obietnicę i swą grą wyprowadził z miasta szkodniki. Gdy po wykonaniu zadania wrócił do miasta, by upomnieć się o swoją należność, został przez mieszczan zignorowany. Ludzie wyparli się złożonej obietnicy. Szczurołap odszedł bez słowa, lecz wkrótce powrócił. Tym razem odziany w czerń, w kapeluszu, z maską na twarzy. Wydobył z fletu bajeczną muzykę, której czarodziejska moc zahipnotyzowała około 130 dzieci mieszkających w Hameln. Zauroczone melodią magicznego instrumentu udały się za swoim przewodnikiem w daleką wędrówkę — i słuch o nich zaginął. Tak oto zemścił się na niewdzięcznych mieszczanach urażony muzyk.

Tyle mówi legenda ${ }^{1}$, którą utrwalono w licznych źródłach historycznych, zarówno literackich, jak i ikonograficznych. Najczęściej cytowanymi przekazami

${ }^{1}$ Dziś historycy tłumaczą zniknięcie dzieci w zupełnie inny sposób. Stanisław Dubiski pisze: „Dopiero w XVI wieku do historii zagłady dzieci dorobiono legendę o szczurołapie, tłumacząc w ten sposób poczucie winy mieszkańców, którzy przez chciwość utracili własne dzieci. Znane fakty o epidemii dżumy w latach 1347-1350 wystarczająco tłumaczą incydent odejścia dzieci, ale w samej bajce o szczurołapie może również tkwić jakieś źdźbło prawdy, choć najprawdopodobniej nie mające nic wspólnego z wydarzeniami 1350 roku. Bajki czy legendy o szczurołapie, który wywabiał gryzonie z domów czy wypędzał je z miasta, posługując się piszczałką (czasem zrobioną 
są Johanna Wolfganga von Goethego ballada Szczurołap oraz baśń o pokrewnym tytule spisana przez braci Grimmów. Zacytujmy Szczurołapa Goethego w przekładzie Andrzeja Lama²:

Gdy ma humor śpiewak czasem,

Także dzieci chętnie łapie,

Co najdziksze też ujarzmi,

Kiedy im zaśpiewa bajki.

Choćby chłopcy krnąbrni byli,

A dziewczynki w kąt się kryły,

Trącę tylko taktów parę,

Już za sobą mam gromadę.

Doświadczony śpiewak czasem

Też dzieweczki chętnie łapie;

W jakiejkolwiek jest mieścinie,

Każdej zrobi coś dziewczynie.

Choćby były jeszcze głupsze,

A kobiety jeszcze suchsze,

Ku miłości chętna każda,

Kiedy słyszy głos śpiewaka.

Żartobliwy charakter, wyczuwalny zwłaszcza we fragmencie o uwodzeniu dziewczyn przez pewnego siebie muzykanta ${ }^{3}$, dowodzi, że Goethemu przyświecały cele adaptatorskie. Wiersz napisany został na potrzeby baletu, jest przekazem twórczo przetworzonej figury literackiej, która zatraca swój pierwotny sens, ponieważ zostaje wtórnie sfunkcjonalizowana. Przeważa w niej ton liryczny, element epicki został całkowicie wyeliminowany. Oznacza to, że legenda o Szczurołapie z miasta Hameln, jeśli traktować ją jako historyczny przekaz, nie znajduje tu swojego odpowiednika. Goethe nie opowiada nam żadnej historii, zakłada bowiem, że legenda, na której kanwie komponuje wiersz, jest czytelnikowi znana. Stąd też wiersz jest bardzo skondensowany i zwarty formalnie. Figura Szczurołapa jest tu podstawą transfiguracji.

W inny sposób motyw legendy wykorzystuje chociażby Robert Browning, który stworzył poemat zbliżony gatunkowo do ballady i bajki, dramatyzujący historię o Szczurołapie. Składa się z piętnastu strof o nieregularnych rozmiarach,

\footnotetext{
z kości szczura), możemy znaleźć w folklorze wielu narodów Europy. Być może, w Europie w XV czy XVI wieku istniał rzeczywiście taki »zawód «”. Por. S. Dubiski, Ile prawdy w tej legendzie?, „Wiedza i Życie” 1999, nr 6, http://archiwum.wiz.pl/1999/99065300.asp [dostęp: 11.02.2019].

2 J.W. von Goethe, Poezje. Faust 1, przeł., oprac. i ryc. dobr. A. Lam, Pułtusk 2012, http:// www.knpk.ah.edu.pl/palio/html.run?_Instance=wsh-postgres\&_PageID=1\&_CatID=976\&_LangID=1\&_CheckSum=-1667113883 [dostęp: 14.01.2019].

${ }^{3}$ A. Lam informuje, że wiersz Der Rattenfänger został opracowany muzycznie przez Franciszka Schuberta. Powstał dla baletu dziecięcego, który wystawiono w Weimarze w 1802 lub 1803 roku. Zob. ibidem.
} 
a co najistotniejsze - kończy się morałem. Oto fragment w przekładzie Jana Lemańskiego ${ }^{4}$ :

Tak, synu, płaćmy, ty jeden, ja drugi

Wszystkim, a zwłaszcza płać Fletnikom długi;

Od szczura zbawią cię, czy od skorpiona,

Płać: obietnica musi być spełniona!

Legenda o fleciście z Hameln była popularnym tematem literackim od początku XIX wieku. Tradycję tę kontynuowali liczni poeci dwudziestowieczni, na przykład Guillaume Apollinaire, Marina Cwietajewa, Aleksandr Grin, Bertolt Brecht, Günter Grass, Carl Zuckmayer, Czesław Miłosz czy Paweł Huelle ${ }^{5}$. Celem niniejszego artykułu będzie wyszczególnienie cech motywu Szczurołapa w kontekście muzyczno-literackim, skonstruowanym przez Władysława Sebyłę, oraz w perspektywie badań nad mitami na podstawie wielu ujęć metodologicznych.

\section{II}

Przytoczona historia miasta Hameln to znamienny przykład sposobu funkcjonowania mechanizmu, który prowadzi do zaistnienia sytuacji konfliktu, determinowanego antynomią jednostka-zbiorowość. Zasadniczym węzłem owej relacji jest korelacja - a więc wzajemne promieniowanie i oddziaływanie. Różni się ona w zależności od strukturalnej spójności wspólnoty. Najważniejszym tej relacji komponentem narracyjnym łączącym perspektywę artysty i jego zaplecze społeczne są mity. Tworzą one płaszczyznę względnego porozumienia, organizują przestrzeń możliwości działania i wzajemnego oddziaływania, a więc swoistego przymusu $^{6}$. Są one operatorami wyobraźni powszechnej, ale i indywidualnej. Najczęstszym przejawem działalności mitotwórczej w jej pragmatycznym wymiarze są mity historiozoficzne i socjopolityczne ${ }^{7}$. Każdy z nich pełni określone funkcje. Oprócz nich należy wymienić tak zwane mity literackie, mity w ramach literatury,

${ }^{4}$ R. Browning, Fletnik z Hamelnu, przeł. J. Lemański, „Kurier Warszawski” 1930, nr 60, s. 10, https://pl.wikisource.org/wiki/Fletnik_z_Hamelnu [dostęp: 11.02.2019].

5 J. Piotrowiak, Ciemny nurt mego życia. O wyobraźni poetyckiej Władysława Sebyły, Katowice 2008, s. 169.

${ }^{6}$ W rozumieniu Émile'a Durkheima, dla którego funkcjonowanie faktu społecznego wiąże się z przymusem: „[Fakty społeczne] polegają na sposobach działania, myślenia i odczuwania, zewnętrznych wobec jednostki, a zawdzięczających swoje istnienie potędze przymusu, za pomocą której narzucają się jednostce", idem, Zasady metody socjologicznej, przeł. J. Szacki, Warszawa 1963, s. 30.

${ }^{7}$ Michał Głowiński proponuje taką definicję mitu socjopolitycznego: „[To takie wypowiedzi], których głównym celem jest oddziałanie na świadomość społeczną za pomocą czynników irracjonalnych (elementy mitów w ideologiach politycznych), tworzenie swoistych wzorów osobowych i wzorów zachowania", idem, Mit, [w:] Słownik terminów literackich, red. J. Sławiński, Wrocław 2000, s. 315. 
mity jako literatura czy literaturę mityczną i mitologiczną ${ }^{8}$. Wszystkie powiązane są ze sferą komunikacji o wymiarze performatywnym, jakkolwiek w odróżnieniu od mitów socjopolitycznych w przeważającej mierze dominuje w nich funkcja estetyczna. W piśmiennictwie zjawisku mityczności towarzyszą specyficzne pisarskie konstrukcje podmiotowe (ten, który do czegoś przekonuje) i przedmiotowe (to, co winno kogoś przekonywać). Element perswazji towarzyszy narracji mitycznej implicite. Zarówno politycy, filozofowie, teoretycy, jak i pisarze traktują mity jako swoiste sposoby wytwarzania wartości, modele przeżywania świata, a także wyraz stosunku wobec zbiorowości - jakiś model nią zarządzania ${ }^{9}$. Myślenie artystyczne nie różni się wiele od działalności politycznej. Sposobem kreowania rzeczywistości i wpływania na sposób myślenia o niej są zabiegi językowe, które odgrywają rolę analogiczną do opowieści mitycznej. Narzucenie sposobu mówienia i opowiadania sprzyja kreowaniu wyobrażenia o świecie zewnętrznym, jego wyposażenia, rozkładu wartości itp. Głównym założeniem niniejszego artykułu jest utożsamienie procesu twórczego z czynnym wykorzystaniem mitu literackiego, służącego do zdekonstruowania na przykład mitu socjopolitycznego. Dekonstrukcja ta jest ukierunkowana w sposób wieloraki, choć najczęściej polega na demistyfikacji normatywnego kodu warunkującego mit. Towarzyszą temu zjawisku bardzo różne motywy, a wykorzystywane są rozmaite narzędzia. Władysław Sebyła czyni użytek zarówno z motywów literackich, jak i muzycznych, łącząc je w charakterystyczny sposób $^{10}$. Powołuje do życia specyficzną — i bodaj pierwszą w polskiej literaturze ${ }^{11}$

${ }^{8} \mathrm{~W}$ tym krótkim artykule zabraknie miejsca na oddanie sprawiedliwości każdemu z wymienionych rodzajów. Warto jednak przypomnieć w tym kontekście o badaniach Northropa Frye'a, który przebadawszy mity różnej proweniencji, postawił tezę, że to z nich w ogóle literatura się wywodzi. Byłaby ona rodzajem zdesakralizowanego mitu. Koncepcja Frye’a spotkała się z aprobatą, ale i ze sprzeciwem. Nie ma tu jednak miejsca na przybliżenie czytelnikowi tego sporu. Por. M. Klik, Teorie mitu. Wspótczesne literaturoznawstwo francuskie (1969-2010), Warszawa 2016, s. 81-86.

${ }^{9}$ Zarządzanie za pomocą mitu jest zazwyczaj niewidoczne, ponieważ występuje on pod postacią sugestywnej opowieści o okolicznościach ważnych dla ukonstytuowania się wspólnoty. To nie tylko przymus, wobec którego można wzniecić bunt, lecz także wewnętrzne przekonanie jednostki, której wyobrażenie wykreowane jest przez mit. Georges Dumézil podkreślał, że „mity nie są nigdy nic nieznaczącymi opowieściami dramatycznymi lub lirycznymi, bez żadnego związku z organizacją społeczną lub polityczną, z rytuałami, z prawem i zwyczajami, lecz — przeciwnie — ich główna rola polega na legitymizacji [porządku społecznego]”, cyt. za: ibidem, s. 163.

${ }^{10}$ Ciekawie pisze o tym Bartosz Małczyński: „Bohater wierszy Sebyły to istota »szumem krwi urzeczona i ptasim zaśpiewem «, wsłuchana w muzykę serca, odtwarzającego »odwieczną krwi piosenkę« i uderzającego »rytmem wielkiego ze światem przymierza《", idem, ,, Muzyka nocy tej”. Komentarz do wybranych wątków muzycznych w poezji Władysława Sebyly i diarystyce Sabiny Sebyłowej, [w:] Władysław Sebyła. Lektury, red. J. Kisiel, E. Wróbel, Katowice 2017, s. 95.

${ }^{11}$ Nie chodzi o jakąkolwiek figurę podmiotową, lecz taką, w której wykorzystane są motywy muzyczne bądź dźwiękowe. Gwoli przykładu: Józef Czechowicz tworzył mity poetyckie, lecz nie stworzył komplementarnej wobec nich figury podmiotowej, która operowałaby nimi za pomocą motywiki muzycznej. Sebyła wydaje się w tym kontekście bardzo oryginalny, tym bardziej że operuje tradycją na poziomie symbolu. Nie jest muzyczny wyłącznie w sposób autoteliczny (w łożysku poetyckim), lecz także na płaszczyźnie użytkowych figur, za których sprawą tradycja w przybli- 
— literacko-muzyczną figurę podmiotową wyposażoną w mechanizm obnażenia i aktualizacji mitu. Podmiot dzierży władzę nie tylko nad słowem, lecz także nad muzycznym dźwiękiem definiowanym kontekstowo ${ }^{12}$.

Przed interpretatorem stoją dwa podstawowe zadania. Pierwszym będzie próba opisania relacji konfliktowej, tej sfery napięć między jednostką a określonym i przyporządkowanym jej kodem kulturowym. Drugim zadaniem będzie omówienie związanych z nią performatywnych strategii językowych. Dla Sebyły słowo miało wymiar ambiwalentny: z jednej strony jest nośnikiem wartości, który jednocześnie może je wytwarzać, ma więc w sobie możliwości kreacyjne — to ono powoływało rzeczywistość do istnienia, do bycia, ono ustalało jej ontologiczny status; z drugiej zaś — oddane na służbę poezji nie zawsze pełni swą funkcję adekwatnie do oczekiwań. Sebyła w wierszu autotematycznym Poeta pisze: „Jak słowem z pluskiem rozmawiać? [...] Jakże mówić z płynącą rzeką? [...] Jakim słowem, wydartym wiekom, / Zmierzyć mętne fale tej głębi?"13. Wiersz stawia nas przed pytaniem: w jaki sposób język może zapanować nad rzeczywistością? Albowiem o ile świat człowieka jako świat wykreowany przez język operuje kategoriami (na przykład mitami) organizującymi przestrzeń międzyludzką, nadającymi jej kształt względnie koherentny, o tyle świat rzeczywisty, a więc realny ${ }^{14}$, niepoddający się presji symbolizowania, jest dla języka, a więc dla człowieka — niedostępny.

Mity nader często służą literaturze, nader często są samą literaturą, a najczęściej po prostu opowieścią, która pełni w ramach literatury pewne określone funkcje. Poziomy mityzacji mogą przebiegać niezależnie od siebie, choć najczęstszym zjawiskiem wydaje się ich wzajemne przenikanie, przecinanie się, wzajemne wpływanie na siebie i determinowanie kształtu. Mit w literaturze ma charakter głównie językowy ${ }^{15}$ - przede wszystkim z powodów materialnych. Niemniej symboliczna i semantyczna warstwa twórczości literackiej nader często pożytkuje mit jako coś albo gotowego i zdolnego do twórczego przetworzenia, na przykład

żeniu wartościuje wykorzystane przez poetę elementy muzyczne. Muzykę waloryzowano wysoko w tradycji zarówno judeochrześcijańskiej, jak i greckorzymskiej.

12 Nie definiowanym więc wyłącznie muzykologicznie, choć od tego rozumienia dźwięku zawsze należy wychodzić. Dla poetów dźwięk jest jednak nie tylko zjawiskiem akustycznym, lecz także wartością. Dźwięk jest waloryzowany i wykorzystywany w procesie ewaluacyjnym, a więc w sytuacji nadawania czemuś jakiejś wartości.

13 W. Sebyła, Poezje zebrane, wstęp i oprac. A.Z. Makowiecki, Warszawa 1981, s. 46.

14 „Realny” zapożyczam z teorii psychoanalitycznej Jacques’a Lacana (zob. idem, Funkcja i pole mówienia i mowy w psychoanalizie, przeł. B. Gorczyca, W. Grajewski, Warszawa 1995), jednocześnie abstrahując od niej. Należy to pojęcie potraktować bezpretensjonalnie i bardziej powierzchownie. „Realny” oznacza w tym wypadku 'pozajęzykowy’ bądź ‘pozasymboliczny'.

15 Warto jednak przypomnieć, co o micie pisał Claude Lévi-Strauss: „Substancja mitu nie tkwi ani w stylu, ani w sposobie narracji, ani w składni, lecz w historii, którą się tam opowiada. Mit jest mową; ale jest to mowa, która porusza się na bardzo wysokim poziomie i gdzie znaczenie odrywa się, jeśli wolno tak powiedzieć, od podstawy językowej, po której początkowo się toczy”, idem, Struktura mitu, [w:] idem, Antropologia strukturalna, przeł. K. Pomian, Warszawa 1970, s. 189. 
wątki mitologiczne różnej proweniencji obecne w tradycji literackiej, albo coś, co należy stworzyć i wymyślić na nowo. Ścierają się wówczas dwie postawy odtwórcza i kreacjonistyczna.

Za Durkheimem można określić mity jako fakty społeczne ${ }^{16}$. Łączył on ściśle pojęcie mitu socjologicznego ze sferą sacrum i wspólną dla danej społeczności religijnej interpretacją świata - była to swoista wykładania jego rozumienia. Był więc mit narzędziem poznawczym. Miał charakter zbiorowy. Nie oznacza to jednak, że w relacji między opowieścią a jej odbiorcą nie występowała struktura hierarchiczna. Mity należało obsługiwać, nie każdy mit ma bowiem taką samą jakość - robiły to figury społeczne w sposób rytualny do tego przeznaczone. Stąd też indywidualne znamię mitu w ujęciu socjologicznym ma znaczenie marginalne. Eleazar Mieletinski podkreślał, że „mit jest głęboko społeczny, a nawet socjocentryczny, gdyż obowiązująca w nim skala wartości określana jest przez wspólny interes rodu, plemienia, miasta, państwa" ${ }^{17}$. Mit ma określoną funkcję performatywną - jego zadanie to określony wpływ na jednostkę w ramach społeczności, rdzeniem wywierania wpływu jest wykreowanie wartości, która będzie dla wszystkich wspólna. Jest narzędziem „kontrolnym”. W literaturze polskiej największym koryfeuszem tego typu myślenia o roli „narodowej narracji” był Cyprian Norwid, gdy pisał w Promethidionie: „Narodowy artysta organizuje wyobraźnię, jak na przykład polityk narodowy organizuje siły stanu" ${ }^{18}$. Norwid nie twierdzi bynajmniej, że poeta i polityk pełnią tę samą funkcję społeczną. Dysponują oni innymi narzędziami, toteż chodzi bardziej o analogiczny sposób wywierania wpływu i sterowania umysłem słuchacza bądź czytelnika poezji (lub generalnie - odbiorcy dzieła sztuki). Polityk zarządza państwem, poeta wyobraźnią „masy ludzkiej”. Można więc powiedzieć, że ich role są w jakiś sposób komplementarne. Towarzyszy temu również specyficzny dla mitu sposób myślenia o prawdzie, zbliżony do pragmatycznego kryterium, które ją warunkuje prawdą jest to, co w sposób skuteczny organizuje zbiorowe wyobrażenie. Dobry poeta to taki, który to potrafi. Program poezji uspołecznionej grupy poetyckiej Kwadryga, do której należał Władysław Sebyła, zbiegał się z tymi przekonaniami, choć nie w sposób ścisły.

Roland Barthes stwierdza, że „mit jest słowem”19, lecz nie jest to słowo dowolne; muszą zaistnieć odpowiednie warunki, ażeby mogło ono pełnić funkcję mitu. Dla francuskiego filozofa i teoretyka literatury musiały to być warunki społecznego zawłaszczenia znaczenia, absolutyzacji i redukcji. Mity polityczne, powiązane z ideologią, mają charakter językowy, bo są ściśle powiązane nie

16 É. Durkheim, op. cit., s. 24-30.

17 E. Mieletinski, Poetyka mitu, przeł. M.R. Mayenowa, Warszawa 1983, s. 211.

18 C. Norwid, Promethidion. Rzecz w dwóch dialogach z epilogiem, oprac. W. Przecławski, Warszawa 1923, s. 35.

${ }^{19}$ R. Barthes, Mitologie, przeł. A. Dziadek, wstęp K. Kłosiński, Warszawa 2008, s. 239. 
z przedmiotem, który je określa, lecz ze „sposobem ich wypowiadania” ${ }^{20}$. Barthes podkreśla znaczenie „,społecznego użytkowania mitu”21 — mitem może stać się wszystko, dlatego że każdy element rzeczywistości może zostać społecznie, a więc językowo - za sprawą mowy i wypowiedzenia — zawłaszczony i zmitologizowany. Barthes nazywa ten proces normatywizacją jakiejś wykładni o świecie. Mamy więc wówczas do czynienia z przesunięciem od Historii do Natury ${ }^{22}$ - słowo naturalizuje Historię, unieruchamia ją, a w konsekwencji ustatycznia zmienność. Mity muszą być natomiast nieruchome, by spełniać swoją funkcję.

\section{III}

W tym punkcie zazębia się semiologiczna teoria mitu Barthes'a z przekonaniami Sebyły. Dla poety figura Szczurołapa jest wszystkim, tylko nie zatrzymywaniem bytu. W wierszu pod tytułem Ksiądz pisze: „Ja nie znam prawdy, a w twoją nie wierzę. / I nie znam tajemnicy człowieka ni gwiazd. / We dnie w przydrożnym rowie umęczony leżę, / Nocą szczury wypędzam z miast"23. W wierszu zaś Spowiedź szczurołapa: „Ja jestem szczurołapem, słodko gram na flecie, / Chodzę, lunatyk nieba, po ogromnym świecie" 24 . Konstrukcja podmiotowa sugeruje ciągły ruch i zmianę - dekonstrukcję porządku świata, który widać. Szczurołap nie działa jawnie, pracuje w nocy, ale za jego sprawą świat się porusza — konkretnie za sprawą jego gry.

Sebyła wydaje się rejestrować społeczną strukturę mitów, używając figur wyjałowionych socjalnie. Oskarża nie tyle samych obsługiwanych przez mit, ile ów mit obsługujących - osobistości zdolne do działalności sensotwórczej i performatywnej. W wierszu pod tytułem Ogłoszenie ${ }^{25}$ czytamy:

\footnotetext{
Obywatele!

Szczurów na świecie za wiele.

W biały dzień wyłażą ze śmietników

I ośmielają się swój pisk

Podnosić do godności człowieczego krzyku.

Zamknąć im pysk!

Wszędzie szczury.

Ubrały się w mundury,

Sutanny i fraki,

A i w purpurze chodzi jaki taki.
}

Można jasno wskazać twórców i operatorów mitycznego porządku, wobec którego poeta nastawiony jest wrogo - są to urzędnicy państwowi, wojskowi oraz

\footnotetext{
${ }^{20}$ Ibidem.

${ }^{21}$ Ibidem, s. 240.

22 Ibidem, s. 262.

${ }^{23}$ W. Sebyła, op. cit., s. 44-45.

24 Ibidem, s. 32.

${ }^{25}$ Ibidem, s. 29-30.
} 
księża i biskupi katoliccy. Te figury określa mianem szczurów, a więc szkodników. Można traktować działania Sebyły jako próbę konfrontacji między porządkami symbolicznymi lub między porządkiem symbolicznym a próbą jego dekonstrukcji. Sebyła spostrzega, że niemożność językowej organizacji świata pozaludzkiego nie spotyka się z rozumieniem wśród operatorów języka. Reprezentanci określonego porządku symbolicznego posługują się językiem w sposób nieudolny, co implikuje stan zafałszowania rzeczywistości. Strach przed demistyfikacją sprawia, że aby utrzymać porządek symboliczny, stosują przemoc. Sebyła pisze: „Gryzą i niszczą wszystko, co im pod pysk wpadnie. / Na nic pułapki, zapadnie"26. W dalszej części wiersza poeta konkretyzuje obrazy. Dla Sebyły z jednej strony porządek symboliczny, który reprezentują figury wymienione przez niego wyżej, jest krzywdzący, ponieważ ma charakter niszczycielski oraz ekspansyjny, z drugiej zaś wiąże się poniekąd $\mathrm{z}$ innymi porządkami językowymi, pojawiają się bowiem $\mathrm{w}$ jego poezji wątki antykapitalistyczne: „,Szzczury] najwyższe góry, sięgające nieba, / Gryzą jak bochny chleba. / Kurzem żelaznej rudy opylone pyski / Nurzają w nafty wytryski. / A niech je ogarnie pragnienie, / Żegnajcie źródła, potoki, strumienie!"27.

Sebyła wprowadza figurę wędrownego muzyka nie bez powodu. Przypomnijmy, że dla Susanne K. Langer i Claude'a Levi-Straussa najwyższym rodzajem mitu jest muzyka ${ }^{28}$. Badacze uznają ją za rodzaj języka, który zdolny jest w jakiś sposób opisać mit ${ }^{29}$. Podobnie dla Sebyły — muzyka jest narzędziem poznawczym, które obnaża prawdy najoczywistsze, najbardziej bezpośrednie, dlatego że jej doświadczanie nie wiąże się z żadnym obranym kodem redukującym typy doświadczenia. Muzyka ma wymiar „magiczny”, nierozpoznany, nie jest zawłaszczona przez żaden język. Stąd też stara legenda o fleciście jest swoiście przetworzoną i zaktualizowaną formą tradycji, którą poeta przetwarza w sposób nowoczesny. Sebyła uprawia bardzo specyficzną działalność interpretacyjną i sensotwórczą. Dodatkowym kontekstem jest nieprzejednana wiara we wpływ, jaki muzyka wywiera na człowieka ${ }^{30}$. Witold Lutosławski zauważył niegdyś, że

${ }^{26}$ Ibidem, s. 29.

27 Ibidem.

${ }^{28}$ Susanne K. Langer nie twierdziła jednak, że muzyka jest rodzajem języka. Z jej punktu widzenia muzyka była pozadyskursywna. Por. M. Kubiak, Susanne K. Langer koncepcja poznania muzycznego jako transformacji symbolicznej, „Roczniki Kulturoznawcze” 2017, $\mathrm{nr} 2$.

${ }^{29}$ E. Kuźma, Mit w literaturze, [w:] Stownik literatury polskiej XX wieku, red. A. Brodzka et al., Wrocław 1995, s. 644.

${ }^{30}$ Warta przypomnienia jest postać Damona, którego wiara w oddziaływanie muzyki na człowieka była tak mocna, że postulował jej absolutną kontrolę przez organa państwowe. Wychowanie muzyczne traktował jako kluczowe w odgórnym kierowaniu rozwojem człowieka. Por. A. Karpowicz-Zbińkowska, Teologia muzyki w dialogach filozoficznych św. Augustyna, Kraków 2013, s. 78. Inna estetyczno-filozoficzna koncepcja dotycząca afektywnych możliwości muzyki, którą stworzyli starożytni pitagorejczycy, mówi, że „muzyką można oddziaływać na duszę. Dobrą muzyką można je ulepszać, ale także złą można ją psuć”, W. Tatarkiewicz, Historia estetyki, t. 1, Warszawa 2009, s. 97. 
słuch ludzki jest zmysłem upośledzonym, ponieważ jest zupełnie bezbronny. Możemy zamknąć oczy, jeśli nie chcemy widzieć, możemy nie jeść, jeśli nam nie smakuje, możemy nie dotykać, jeśli nas parzy. Natomiast nic nie pomoże zatykanie uszu, a nawet zalepianie ich woskiem, jeśli nie chcemy słyszeć. Dźwięki dochodzą do nas poprzez czaszkę. Słuch nasz jest bezbronny i pod tym względem jesteśmy niewolnikami otaczającego nas świata ${ }^{31}$.

Muzyka i dźwięk są z natury ekspansywne, narzucają się człowiekowi. Siła muzyki tkwi też w słabości człowieka, jego podatności na wpływ. To tłumaczyłoby motywy, którymi kierował się Sebyła, rekonstruując postać flecisty z Hameln.

Działalność Sebyły oscylowała na krawędzi. W Polsce międzywojennej czynnym organem państwowym była cenzura. Wyróżnia się trzy tematy „drażliwe" w międzywojniu ${ }^{32}$. Po pierwsze, zagadnienia społeczne i polityczne, a więc krótko mówiąc: krytyka władzy, zwłaszcza z pozycji lewicowych lub centrowych - liberalnych, socjalistycznych i komunistycznych. Po drugie, obyczajowość, a zatem swoiście rozumiany i penalizowany wówczas pornografizm w sztuce. Po trzecie, obraza „uczuć” religijnych, znana dawniej jako bluźnierstwo. Trzeci typ powiązany był z tematyką obyczajową, choć w tym wypadku to państwowe instytucje stanowiły rękojmię cenzury kościelnej. Działalność cenzury sukcesywnie wzrastała od początku lat trzydziestych, czego ponurym symbolem był tak zwany proces brzeski z lat 1931-1932. Można przyjąć, że Sebyła w sposób ironiczny odnosił się również do instytucji zarządzającej językiem i systemem symboli, gdy pisał, że „Szczurołap, gładząc tłuszczem namaszczone włosy, / Błądzi i gra na flecie pieśni zakazane. / Gra melodie jak wierzby srebrne i zielone"33.

Sebyła ostrożnie posługuje się mitem. Nie jest on dla niego tym samym co na przykład dla Józefa Czechowicza czy Bolesława Leśmiana. Bo o ile dla Czechowicza $^{34}$ i Leśmiana ${ }^{35}$ mity nie tworzyły koniecznie opowieści organizującej

${ }^{31}$ Niniejszy fragment wypowiedzi pochodzi z wywiadu, którego Witold Lutosławski udzielił dla Polskiego Radia; cyt. za: L. Erhardt, Sztuka dźwięku, Warszawa 1980, s. 64.

32 A. Zawada, Dwudziestolecie literackie, Wrocław 2000, s. 201-203.

33 W. Sebyła, op. cit., s. 39.

${ }^{34}$ Czechowiczowi zdarzało się traktować mit pojmowany jako kategorię poetologiczną (model kreowania świata przedstawionego) w sposób zbliżony do mitu socjopolitycznego. Różnica polegała jednak na tym, że dla Czechowicza świat wykreowany artystycznie miał być pojmowany w kategoriach mitu, który służył głównie jako narzędzie poznawcze i kreujące jednocześnie. Można by więc wyróżnić u Czechowicza dwa przynajmniej funkcjonalne rozumienia mitu. Po pierwsze, jako kategorię związaną z tak zwaną postawą mitotwórczą, a więc przekonaniem o kreacyjnym potencjale sztuki poetyckiej, która może stanowić realną przeciwwagę wobec skrajnego zmaterializowania i zracjonalizowania widzialnego świata (zob. T. Kłak, Czechowicz - mity i magia, Kraków 1973, s. 121-122); po drugie, jako kategorię, która jest użyteczna poznawczo na poziomie społecznym - albowiem mit poetycki może według Czechowicza równie skutecznie „prowadzić społeczności ku lepszemu jutru, jak doktryny socjalne czy religijne”, T. Kłak, Wyobraźnia stwarzająca, [w:] idem, Reporter róż. Studia i szkice literackie, Katowice 1978, s. 14-15.

${ }^{35}$ U Leśmiana „mity nie są powoływane na stałe, jako stałe przekonania ontologiczne, a więc przekonania o rzeczywistości. Są to niejako przekonania pomocnicze, powołane na to, aby wyłonić się i zniknąć po spełnieniu swojej roli. Leśmian nazywał to baśnią", J. Trznadel, Wstęp, [w:] B. Leśmian, Poezje wybrane, oprac. J. Trznadel, Wrocław 1991, s. XXX. 
porządek społeczny, były wszak bardziej narzędziami poetyckiej kreacji i projektami jakiegoś rozumienia świata, o tyle dla Sebyły mit miał wymiar bardziej konkretny. Wykorzystanie legendarnej figury kulturowej może mieć podwójne znaczenie. Po pierwsze, służy do skonstruowania mitu literackiego, istniejącego w obrębie literatury jako narzędzie organizujące zarówno strukturę świata przedstawionego, jak i jego odbicie w sferze realności i wartości. W tym sensie jest przeciwwagą dla mitu socjopolitycznego, którego charakter jest zawsze redukujący. Po drugie, jest wyrazem spożytkowania charakterystycznej dla Sebyły wyobraźni muzyczno-literackiej.

Muzyka jest dla Sebyły porządkiem o innym znaczeniu niż język. Bo o ile powtórzymy za Johnem L. Austinem ${ }^{36}$, że język miewa charakter performatywny, o tyle o muzyce mówi się, że wchodzi w związki ze sferami emocjonalnymi, afektywnymi. Tymczasem Sebyła tworzy konstrukcję intelektualną, wyposaża swojego bohatera w ,wiedzę” i ,władzę”. Szczurołap widzi, kto jest szczurem, i wie, kogo należy usunąć. To muzyka płynąca z fletu ma tutaj charakter performatywny, albowiem to poprzez ten instrument bohater ,się wypowiada":

Gram kołysanki srebrne na siedmiu świetlistych tonach,

A szczury tańczą sennie na długich, złuszczonych ogonach.

$[\ldots]$

Wsłuchane w pluski fujarki

Toczą piskliwe pogwarki,

Idą za mną — w takt fletu z wolna się kolebią —

I toną po jednemu, powoli -

W czarnej, rodzajnej roli,

W moim złocistym niebie.

Do najważniejszych składników kompozycji całego tomu poetyckiego Pieśni Szczurołapa z 1930 roku zaliczyłbym nie tylko samą postać Szczurołapa, lecz także jego instrument, któremu poeta nadaje bardzo ciekawe znamiona.

Narzędziem Szczurołapa jest instrument. Sebyła nadaje mu moc i podwójną symbolikę, sprzeniewierzając się tradycji sielankowej i pasterskiej, w której flet i fujarka oraz wszelkie ich odmiany waloryzowano niemal zawsze pozytywnie jako nośnik pozytywnej aksjologii ${ }^{37}$. Tymczasem poeta proponuje nam zupełnie inny tryb literackiego odczytywania symboliki instrumentu, jakim jest flet ${ }^{38}$. Po

${ }^{36}$ Austin nazywał performatywne elementy języka „wyrażeniami dokonawczymi”, idem, Mówienie i poznawanie. Rozprawy i wyktady filozoficzne, przeł. i oprac. B. Chwedeńczuk, Warszawa 1993, s. 314.

37 Muzykę pasterską waloryzowano pozytywnie, warunkowała to bowiem konwencja sielankowości. Arkadia jako kraina wiecznej szczęśliwości była przestrzenią pozbawioną powabu dysonansu. Co ciekawe, w Państwie Platon przekonuje, że należy ograniczyć liczbę instrumentów, na których można wykonywać muzykę, i sprowadzić do jednego — do fujarki pasterskiej. Por. A. Karpowicz-Zbińkowska, op. cit., s. 77.

${ }^{38}$ Przekazy biblijne wskazują na postać Jubala jako tego, który dał początek wszystkim muzykom posługującym się fletem. Por. P. Towarek, Chrześcijańska symbolika instrumentów muzycznych, „Studia Elbląskie” 2014, nr 15, s. 222. Tradycja grecka wskazuje na muzę Euterpe, patronkę 
pierwsze, nadaje instrumentowi walory narzędzia niszczycielskiego. Zrównuje go z bronią białą, którą można kogoś uśmiercić: „Nie lituj się nade mną, nie uśmiechaj słodko, / Bo widzę w tobie szczura, co gryzie mi serce! / Bo cię świstem fujarki jak szpadą przewiercę!"39. Po drugie, flet okazuje się medium zdolnym do transgresji. Możliwe jest w jego ramach przekraczanie granicy profanum i sacrum — umożliwia rozmowę z Bogiem ${ }^{40}$. Tak oto poeta obrazuje proces kreowania bóstwa:

Ja mam swojego boga, który jest obłokiem,

Krzepkokorzennym drzewem, wiosennem, wysokiem,

$[\ldots]$

Jest wichrem, który huczy nad wzbudzonym morzem,

Jest dźwięczną muchą w słońcu, wilgotnym parowem

I jest nowym, przeze mnie wymyślonym słowem.

Po trzecie, instrument jest elementem ewokującym obrazy w wierszu, na przykład dźwięk fletu jest utożsamiany z odgłosami przyrody. Można tutaj mówić o komplementarności porządku muzycznego z porządkiem audiosfery ${ }^{41}$ :

Gra melodie jak wierzby srebrne i zielone,

Jak wierzby utopione w księżycowej wodzie,

Jak stawy zabagnione zzieleniałym glonem,

Jak liście drżące w chłodzie.

$[\ldots]$

Szczurołap gra na flecie i rozmawia z bogiem.

Z woskowym oficerem, poetą i księdzem.

Co ciekawe, Szczurołap „nie śpiewa”42, mimo że słowo jest dla niego budulcem i narzędziem kreacji zarazem. Tymczasem potrzebuje narzędzia - bardzo interesująco skonstruowanego symbolicznie instrumentu muzycznego łączącego porządki dźwiękowe.

pieśni lirycznej, do której atrybutów należały dwa flety (aulos). Por. C. Ripa, Ikonologia, przeł. I. Kania, Kraków 2013, s. 291-292.

39 W. Sebyła, op. cit., s. 45.

${ }^{40}$ Sebyła, interpretując rzeczywistość sacrum, a także jej punkt centralny — Boga lub boga — wpisuje się w tradycję hermeneutyczną, w której Bogu przypisywano pewne własności. Dobrym przykładem jest działalność niejakiego Honoriusza z Autun, który „wpisał się w patrystyczno-średniowieczny nurt określania samego Boga Stwórcy jako najwyższego Muzyka. Według Honoriusza Bóg, jako najzdolniejszy Lutnik, zbudował Universum na kształt potężnej cytry, której struny stanowiły duch i materia, chóry niebieskie, niebo i piekło, żywioły i to wszystko, czego doświadczają zmysły", P. Towarek, op. cit., s. 228.

${ }^{41}$ Audiosferę definiuję za Tomaszem Misiakiem jako „fluktuujące uniwersum dźwiękowe, które na przestrzeni wieków ze zmiennym natężeniem wikła nas w niejednorodne i płynne zależności absorbcyjno-emisyjne", idem, Estetyczne konteksty audiosfery, Poznań 2009, s. 38.

42 ,Śpiew” utożsamiany jest tu z poetyckim aktem kreacji. Jest to akt nie tylko performatywny (wywierający trwały skutek — wypowiedzenie słowa poetyckiego), lecz także symboliczny. 


\section{IV}

Tom Pieśni Szczurołapa odczytywano zazwyczaj za pomocą klucza kwadryganckiego - jako wyraz poezji społecznie zaangażowanej. Wiąże się to rzecz jasna z przełomem, jaki dokonał się w polskiej poezji lat trzydziestych, to znaczy zwrotem ku tematyce społecznej. Tadeusz Nyczek, omawiając poezję Sebyły, dostrzega dwie strategie „społecznego" działania. Po pierwsze, poeta głównymi bohaterami swoich wierszy czyni ludzi w jakiś sposób upośledzonych przez los (ślepca, suchotnika, głuchego, włóczęgę, grajka ulicznego itp.); po drugie, stosuje „naturalistyczne utożsamienie losu zwierzęcia i losu człowieka"43, co miało być pokłosiem niesprawiedliwej struktury społecznej, zwłaszcza w obliczu kapitalistycznej machinerii sprowadzającej człowieka do roli zwierzęcia pociągowego pracującego na rzecz „królów i panów brzuchatych" ${ }^{\text {— }}$ — by posłużyć się metaforyczną formułą Juliana Tuwima.

W kontekście twórczości Sebyły sytuacja nie wygląda chyba jednak aż tak prosto. Wydaje się, że dla autora Młynów relacja między etyką a estetyką nie była oparta kontrastowo. Jest skomplikowana, niemniej bardzo komplementarna. Etyka nie istnieje bez estetyki. Każde słowo ma swoją wagę i jakiś artystyczny profil. Należy podkreślić, że porządek aksjologiczny Sebyły jest obudowany ciekawą konstrukcją nie tylko literackiej miary. Tworzy poeta płaszczyznę intermedialną ${ }^{45}$, na której współgra porządek poetycki i muzyczny. Każdy z porządków jest rodzajem medium, które przekazuje jakiś komunikat, ale również wzajemnie na siebie oddziałuje. Choćby bardzo ciekawie ujmuje Sebyła problematykę językową, którą musi poeta dopowiedzieć dyskursem muzycznym, figurami obcej proweniencji.

Badacze twórczości Sebyły dostrzegali wyjątkowość przyjętej przez niego formuły. Tadeusz Kłak napisał, że „Szczurołap jest jedynym sprawiedliwym i tylko on uosabia siły dobra, przeciwstawiając się całej rzeczywistości we wszystkich jej ujemnych przejawach"46. Podobnie myśli Jan Piotrowiak, który zalicza Szczurołapa do „naprawczych tego świata" ${ }^{77}$. Ważnym elementem figury Szczurołapa jest ponadto motyw sprawowania władzy z użyciem dźwięków, co w jakimś stop-

43 T. Nyczek, Dialog z samym soba - Władysław Sebyła, [w:] Poeci dwudziestolecia międzywojennego, red. I. Maciejewska, Warszawa 1982, s. 162.

44 J. Tuwim, Do prostego człowieka, ,Robotnik” 1929, nr 305, s. 2.

45 Jak przekonuje Magdalena Wasilewska-Chmura: „Zjawiska intermedialne są możliwe do uchwycenia poprzez konfrontację form artystycznych, która ujawnia cechy specyficzne i różnicujące dla zaangażowanych mediów, ponieważ medium jest jakością zapewniającą unikalny charakter formy artystycznej”, eadem, Przestrzeń intermedialna literatury i muzyki. Muzyka jako model i tworzywo w szwedzkiej poezji późnego modernizmu i neoawangardy, Kraków 2011, s. 30.

46 T. Kłak, Pejzaże Władysława Sebyty, [w:] idem, Ptak z węla. Studia i szkice literackie, Katowice 1984, s. 148.

${ }^{47}$ J. Piotrowiak, op. cit., s. 165. 
niu nawiązuje do mitu o Orfeuszu ${ }^{48}$. Szczurołap staje się jakimś przewrotnym rodzajem współczesnego Orfeusza-antykapitalisty i wywrotowca.

Sebyłowej narracji sprzyjała rzecz jasna sytuacja społeczno-ekonomiczna kraju. Ale też szeroko rozumiane lewicowo-socjalne otoczenie. Poeta często widział świat w kategoriach kata i ofiary. Katem jest w tym wypadku porządek kapitalistyczny, wyzyskujący, a także jego beneficjenci - finansjera, władza, wojsko i Kościół katolicki; ofiarami zaś - nie tylko prości obywatele, lecz także artyści. Bycie ofiarą nie oznacza jednak dla Sebyły bycia kimś słabym. Potęgą, w którą wierzy, jest sztuka, twórczość, piękno, świat rzeczywisty. W wierszu Jehowa kpi sobie wręcz z figury Boga - jako tego, o którym już nikt nie pamięta, nawet ci najczęściej uzurpujący sobie prawo do wypowiedzi w jego imieniu ${ }^{49}$ :

Zestarzałeś się, mój Boże, zestarzałeś,

Opuściły cię anioły i szatany.

Siwobrody kiwasz głową za kryształem,

Głuchy jesteś, ślepy jesteś, zapomniany.

Byłeś panem ponad ziemią, niebem, morzem...

W pas kłaniały ci się zioła, zboża, dęby;

Teraz kłamią i mordują w imię boże,

Oszukują, wycierają sobie gęby.

Nikt już sobie teraz z ciebie nic nie robi $[\ldots]$

Podmiot Sebyły obraca w pył porządek społeczny, który tylko pozornie jest odrealniony. Dla niego mit ma wymiar realny, toteż należy go zdekonstruować za pomocą innej figury mitologizującej. Eksponowaną figurą, której poświęca sporo miejsca, jest ksiądz. Dla Sebyły-Szczurołapa to symbol tępej redukcyjnej interpretacji rzeczywistości i niszczycielskiej roli dyskursu, który sprowadza różne typy poznania do jednego ,prawdziwego". Jest on wprost nazywany szumem, który nawet swego Boga nie rozumie, wszak ciągle go zdradza. Dla Sebyły figura księdza służy jako przykład literackiej personifikacji bezmyślności ${ }^{50}$ :

Księże! Przestań mnie straszyć swoim bogiem strasznym,

Który siedzi na tronie $\mathrm{z}$ gwiazd i adamaszku.

Przestań syczeć jak żmija. Przestań mówić do mnie.

Nie słyszę. - Zgłuchłem w ciszy.

$[\ldots]$

Nie strasz mnie bogiem, który za zielonym stołem

Siedzi i świat świdruje złym, sędziowskim okiem.

Ja jestem szczurołapem, słodko gram na flecie.

${ }^{48}$ Konstatacja ta dotyczy nie ściśle rozumianej tradycji orfejskiej, lecz jej uniwersalistycznego wymiaru. Maciej Jaworski zauważa, że istnieje nurt interpretacyjny dotyczący motywiki orfejskiej, który luźno nawiązuje do pierwowzoru: „Każdego pisarza równie przekonująco nazwać można imieniem legendarnego śpiewaka", idem, Nowoczesny Orfeusz. Interpretacje mitu w literaturze polskiej XX-XXI wieku, Warszawa 2017, s. 35.

${ }^{49}$ W. Sebyła, op. cit., s. 40.

${ }^{50}$ Ibidem, s. 31-32. 
Chodzę, lunatyk nieba, po ogromnym świecie.

Nie strasz mnie, księże, niebem, sądem ani burzą!

Bo zagram ci na flecie kołysankę szczurzą.

I pójdziesz za mną w tropy, przed siebie, przed siebie...

A ja cię oplączę, zatopię, utopię...

W moim — złocistym — niebie.

[...]

Nie chcę twojego nieba, gdzie brzmią święte hymny,

Moje niebo jest mroźne jak szkło,

Zimne jak lód zimny.

Moje niebo jest głębokie, głę-bo-kie...

Spróbuj, księże, przeniknąć je swym siwym okiem

Do dna... do dna...

Figurą, w której mamy do czynienia ze starciem jednego mitu z drugim, jest „niebo”. Mitologia katolicka proponuje nam określoną eschatologiczną interpretację raju na podstawie swoistego dla siebie paradygmatu obietnicy. Figura Szczurołapa dekonstruuje tę figurę przez proste zaprzeczenie i deklarację negatywną: „Nie wierzę”. Sebyła dostrzega pęknięcie w narracji mitycznej usiłującej porządkować życie symboliczne kultury polskiej w międzywojniu. Otóż figura Boga, która winna być naczelną kategorią organizującą życie społeczne, straciła na znaczeniu i stała się własną karykaturą.

Przede wszystkim poeta dostrzega redukującą naturę mitów socjopolitycznych i religijnych, które wykorzystują ową figurę w sposób doraźny, tworząc niejako sprzeczność między jej absolutnością i doniosłością a niewydolnością celów, dla których została spożytkowana. Mity powinny bowiem służyć zarówno jednostce, jak i zbiorowości. Pisze o tym Wojciech Wrzesiński: „Mity wyrastają zazwyczaj z artykułowania informacji jednostkowych, ale związanych z myśleniem zbiorowym, z ukształtowaniem się pamięci społecznej. Dokonuje się to w okolicznościach uniwersalizacji, przekształcania informacji o wydarzeniach jednostkowych w uogólnienia" ${ }^{\text {". }}$. Sebyła usiłuje zwrócić uwagę na dysonans między interesem zbiorowości a interesem indywiduum. Mity socjopolityczne oparte na propagandzie są dla poety nie do zaakceptowania z powodu swej powierzchowności, wszak przeciwstawia im swoje własne „niebo, które jest głę-bo-kie”. Jedynym ratunkiem przed obezwładniającym słowem jest słowo własne - słowo, w którym poeta rzeźbi niczym w twardym materiale, powołując do życia figury, które nadają koherentny sens jego własnemu poczuciu świata. Sebyła wprowadza figurę boga poetyckiego, ażeby rozszyfrować, ujawnić i uwolnić Boga zakodowanego w mitach socjopolitycznych.

${ }^{51}$ W. Wrzesiński, Polska mitologia polityczna XIX i XX wieku, [w:] Polskie mity polityczne XIX i XX wieku, [b.red.], Wrocław 1994, s. 11. 


\section{Bibliografia}

Austin J.L., Mówienie i poznawanie. Rozprawy i wykłady filozoficzne, przeł. i oprac. B. Chwedeńczuk, Warszawa 1993.

Barthes R., Mitologie, przeł. A. Dziadek, wstęp K. Kłosiński, Warszawa 2008.

Browning R., Fletnik z Hamelnu, przeł. J. Lemański, „Kurier Warszawski” 1930, nr 60, https:// pl.wikisource.org/wiki/Fletnik_z_Hamelnu.

Dubiski S., Ile prawdy w tej legendzie?, „Wiedza i Życie” 1999, nr 6, http://archiwum.wiz.pl/1999 199065300.asp.

Durkheim É., Zasady metody socjologicznej, przeł. J. Szacki, Warszawa 1963.

Erhardt L., Sztuka dźwięku, Warszawa 1980.

Głowiński M., Mit, [w:] Słownik terminów literackich, red. J. Sławiński, Wrocław 2000.

Goethe J.W. von, Poezje. Faust 1, przeł., oprac. i ryc. A. Lam, Pułtusk 2012, http://www.knpk.ah.edu. $\mathrm{pl} / \mathrm{palio} / \mathrm{html} . r u n ?$ Instance $=$ wsh-postgres\&_PageID $=1 \&$ CatID $=976 \&$ LangID $=1 \&$ CheckSum $=-1667113883$.

Jaworski M., Nowoczesny Orfeusz. Interpretacje mitu w literaturze polskiej XX-XXI wieku, Warszawa 2017.

Karpowicz-Zbińkowska A., Teologia muzyki w dialogach filozoficznych św. Augustyna, Kraków 2013.

Klik M., Teorie mitu. Wspótczesne literaturoznawstwo francuskie (1969-2010), Warszawa 2016.

Kłak T., Czechowicz - mity i magia, Kraków 1973.

Kłak T., Pejzaże Władysława Sebyły, [w:] idem, Ptak z węgla. Studia i szkice literackie, Katowice 1984.

Kłak T., Wyobraźnia stwarzająca, [w:] idem, Reporter róż. Studia i szkice literackie, Katowice 1978.

Kubiak M., Susanne K. Langer koncepcja poznania muzycznego jako transformacji symbolicznej, „Roczniki Kulturoznawcze” 2017, nr 2.

Kuźma E., Mit w literaturze, [w:] Stownik literatury polskiej XX wieku, red. A. Brodzka et al., Wrocław 1995.

Lacan J., Funkcja i pole mówienia i mowy w psychoanalizie, przeł. B. Gorczyca, W. Grajewski, Warszawa 1995.

Lévi-Strauss C., Struktura mitu, [w:] idem, Antropologia strukturalna, przeł. K. Pomian, Warszawa 1970.

Małczyński B., „,Muzyka nocy tej”. Komentarz do wybranych wątków muzycznych w poezji Władystawa Sebyty i diarystyce Sabiny Sebyłowej, [w:] Władystaw Sebyła. Lektury, red. J. Kisiel, E. Wróbel, Katowice 2017.

Mieletinski E., Poetyka mitu, przeł. M.R. Mayenowa, Warszawa 1983.

Misiak T., Estetyczne konteksty audiosfery, Poznań 2009.

Norwid C., Promethidion. Rzecz w dwóch dialogach z epilogiem, oprac. W. Przecławski, Warszawa 1923.

Nyczek T., Dialog z samym soba - Władysław Sebyła, [w:] Poeci dwudziestolecia międzywojennego, red. I. Maciejewska, Warszawa 1982.

Piotrowiak J., Ciemny nurt mego życia. O wyobraźni poetyckiej Władysława Sebyły, Katowice 2008.

Ripa C., Ikonologia, przeł. I. Kania, Kraków 2013.

Sebyła W., Poezje zebrane, wstęp i oprac. A.Z. Makowiecki, Warszawa 1981.

Tatarkiewicz W., Historia estetyki, t. 1, Warszawa 2009.

Towarek P., Chrześcijańska symbolika instrumentów muzycznych, „Studia Elbląskie” 2014, nr 15. 
Trznadel J., Wstęp, [w:] B. Leśmian, Poezje wybrane, oprac. J. Trznadel, Wrocław 1991.

Tuwim J., Do prostego człowieka, „Robotnik” 1929, nr 305.

Wasilewska-Chmura M., Przestrzeń intermedialna literatury i muzyki. Muzyka jako model i tworzywo w szwedzkiej poezji późnego modernizmu i neoawangardy, Kraków 2011.

Wrzesiński W., Polska mitologia polityczna XIX i XX wieku, [w:] Polskie mity polityczne XIX i XX wieku, [b.red.], Wrocław 1994.

Zawada A., Dwudziestolecie literackie, Wrocław 2000.

\section{Poles from the town of Hameln. Language and music strategies of mythologization and demythologization of reality in the poetry of Władysław Sebyła}

\section{Summary}

Myths are the general operators of mass imagination. There is a parallel between the world of politics and the world of literature, and this is why we can find some specific types of constructs of subjectivity and objectivity on both sides, which leads us to ascertainment that politicians and writers use some models of narration to create their own reality, values and models of world understanding. The main assumption of this paper is to equate the process of literary creation and usage of literary myths because both of them are used to deconstruct socio-political myths.

Keywords: socio-political myths, literary myths, music, poetry, God, anti-clericalism, Władysław Sebyła 